\title{
SÕNAVÕISTLUSEL VÄLJAPAKUTUD SÕNADE JUURDUMISEST
}

\author{
RAINER KÜNGAS
}

\section{Sissejuhatus}

\begin{abstract}
A astal 2002 otsiti sõnavõistlusel eestlasele suupärasemaid vasteid kaheteistkümnele Euroopa Liidu tekstides tihti esinevale sõnale või sõnaühendile [ad hoc-komisjon, globaliseerumine, (Euroopa) integratsioon, kriisireguleerimine, nulltolerants, opt-in/opt-out, subsidiaarsus, struktuurifondid, task force, twinning, valitsusväline organisatsioon ja (ühenduse) acquis ] (Erelt 2003). Võistlusest on möödas enam kui kümme aastat, mis võimaldab teha esmaseid järeldusi väljapakutud sõnade juurdumise kohta eestlaste keelekasutuses. Autorile teadaolevalt on siinse uurimuse näol tegemist esimese kvantitatiivse analüüsiga sellel teemal.
\end{abstract}

Sõnavõistlus on keelekorralduse vaatepunktist mitmes mõttes ainulaadne vahend. Esiteks aitab ürituse võistluslik moment kaasata keeleloomesse inimesi, kes igapäevaselt keeleküsimustega ei tegele. Nii 2002. kui ka 2010. aasta sõnavõistlused üllatasid korraldajaid rahva aktiivse osavõtuga (Erelt 2003; Rekand, Ratt 2010). Võistlusega seotud aktiivne meediakajastus soosib väljapakutud vormide kiiret laialdast omaksvõttu või väljapraakimist - see on tendents, mida täheldati juba 1972. aasta sõnavõistluse ajal (Habicht 2005; Kasik 2004: 6). Keele diakroonilise analüüsi seisukohalt loob sõna „massidesse paiskamine" aga ainulaadse olukorra, kus uue keelendi esmakasutuse aja saab määrata ühe päeva, tänapäeval lausa mõnetunnise täpsusega. Selline täpne määrang võimaldab detailselt uurida sõna kasutuselevõtu dünaamikat, mis on sõnavõistlusevälise keeleuuenduse korral märksa keerulisem (vt nt Chalvin 2011; aga ka Milroy, Milroy 1985: 348). Lisaks võib spekuleerida, et tehissõnal, mille on samaaegselt ja üksteisest sõltumatult välja pakkunud mitu keelehuvilist (sõnavõistlustel sage nähtus), on suurem tõenäosus kasutusse minna kui üksusel, mille on välja pakkunud üksainus keeleuuendaja.

Siinses artiklis analüüsitakse 2002. aasta sõnavõistlusel välja pakutud keelendite levikut ajakirjandustekstides. Ajakirjandusel on määrav roll tänapäeva eesti keele säilitamisel ja arendamisel. On märgitud, et „millist keelt kasutab ajakirjandus, niisugust keelt kasutame ka meie, vähemalt suur osa meist" (Kasik 2004: 5). Seega võib eeldada, et uudissõnadel, mida ei võta omaks ajakirjandus, on väga väike tõenäosus jõuda laialdasemasse kasutusse, samal ajal kui ajakirjanduses tihti kasutatavad sõnad võetakse kiiremini omaks.

Täpsemalt on artiklis uurimise alla võetud nii uute kui ka esialgsete vormide kasutus aastatel 2000-2009 ilmunud Eesti Päevalehe artiklites. Aastate 2000-2006 andmed pärinevad eesti keele Koondkorpusest (EKK), aastate 2007-2009 keelekasutuse analüüsiks loodi Eesti Päevalehe internetiarhiivi põhjal uus korpus. ${ }^{1}$ On oluline märkida, et andmete piiratud mahu ja kitsalt

\footnotetext{
${ }^{1}$ Ka Koondkorpuse Eesti Päevalehe tekstid pärinevad väljaande internetiarhiivist, seega
} 
ühele väljaandele keskendumise tõttu tuleb järgnevate tulemuste üldistamisel olla ettevaatlik (Biber 1993: 243). Laiahaardelisema uuringu teostamine takerdub praegu 2000. ja 2010. aastate tekstide puudumise taha Eesti Kirjakeele Korpuses (nt uusimad Postimehe tekstid korpuses pärinevad aastast 2000).

Sõnavõistluse tulemuste analüüsimisel lähtuti sotsioloogias laialdaselt tuntud Everett Rogersi uuenduste leviku teooriast (Rogers 1962; 2003: 1-38), mille põhimõtteid on hiljutises artiklis hästi kirjeldanud Antoine Chalvin (2011: 487-491). Selle teooria kohaselt võib igasuguste uuenduste levikut (alates uut tüüpi umbrohumürkide kasutuselevõtust Ameerika keskläänes ja lõpetades nutitelefonide levikuga Eestis) kirjeldada S-kujulise graafikuga (vt joonist 1a). Graafiku abstsissteljeks on aeg (nt kuudes või aastates), ordinaatteljeks aga uuenduse protsentuaalne levik (nimetatud artiklis on selleks uudissõna esinemise suhteline sagedus korpuses). Esialgu on uuenduse levik piiratud, seda kasutab vaid võrdlemisi väike grupp inimesi (kokkuleppeliselt $2,5 \%$ ), keda iseloomustab soov uusi asju proovida ning keda Rogers nimetab novaatoriteks. Neile järgnevad uuenduse varased omaksvõtjad (järgmised 13,5 \%), varane enamus (34 \%), hiline enamus (34 \%) ning lõpuks viivitajad ja uuenduse vastased (viimased $16 \%$ ) (Rogers 2003: 281). Uuenduse omaksvõtjate arvu muutumist ajas kirjeldab seega Gaussi ehk normaaljaotus (vt joonist 1b). Matemaatiliselt on joonisel 1b kujutatud funktsioon lihtsalt joonisel 1a näidatud funktsiooni tuletis, S-kujulist kõverat saab aga matemaatiliselt kirjeldada veafunktsiooniga (Rõõm 2010: 61-64).

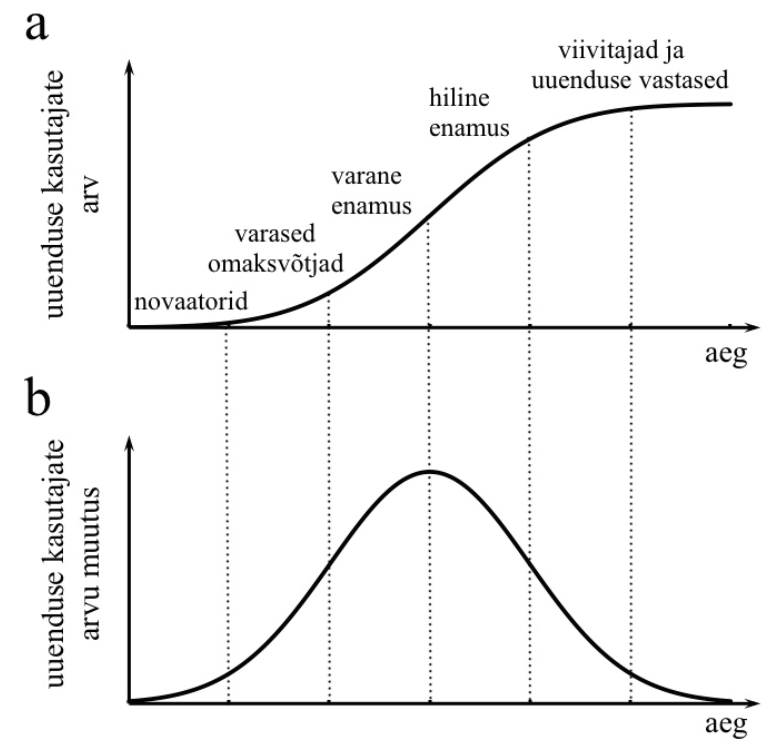

J o o n i s 1. Uuenduste levikut iseloomustavad graafikud: a) uuenduse kasutajate arvu (kasutamise suhtelise sageduse) muutumine ajas, b) uuenduse kasutajate arvu (kasutamise suhtelise sageduse) suurenemise muutumine ajas (Rogers 2003: 281).

võib eeldada, et loodud korpus ja Koondkorpus on sarnase kronoloogilise tiheduse ja representatiivsusega. Eeldust kontrolliti 2007. aasta tekstide põhjal, kus kaks korpust kattusid. Analüüsi tulemused korpuse valikust ei sõltunud. 
Klassikaline uuenduste leviku teooria käsitleb ühesuunalisi uuendusi, s.t uuendusi, mis levima hakates jõuavad alati edukalt laialdasse kasutusse (Rogers 1962: 150). Uuenduste ühesuunaline ja pidev levikuahel on aga siiski pigem erand kui reegel. 1890. aastal Gabriel de Tarde sõnastatud eesmärk „mõista, miks sajast samal ajal välja pakutud uuendusest.... levib laialdasemalt vaid kümme, samal ajal kui 90 neist unustatakse" (Tarde 1903: 140), on jätkuvalt aktuaalne. Ebaõnnestunud uuenduste leviku uurimine on keerulisem, sest protsessi esimestel astmetel on uuenduse olemasolust teadlik vaid väike osa ühiskonnast. Uuenduse leviku protsessis võib esineda pikki viivitusi ja tagasiminekuid, s.t teatud välise mõjuri toimel võib uuenduse kasutuselevõtt pidurduda või isegi pöörduda (Rogers 2003: 112-114). Seda fenomeni on uuritud ka lingvistikas, näiteks grammatisatsiooniteooria (Heine 1993: 48-49; Hopper, Traugott 2003: 49, 124-125) raames. Sõnaloomet ja uute sõnade levikut, eriti aga Johannes Aaviku ja teiste keeleuuendajate mõju tänapäeva eesti keelele on põhjalikult uuritud (vt näiteks Raag, V. 1998; Raag, R. 2008; Erelt, Kull, Meriste 1985). Siinse artikliga seoses tuleb varasematest töödest esile tõsta Kadi Mihkla magistritööd „Võõrsõnad Eesti õigusaktides ja Euroopa Liidu õigusaktide tõlgetes” (Mihkla 2010) ja Antoine Chalvini artiklit „Johannes Aaviku keeleliste uuenduste levik" (Chalvin 2011). Viimast ja siinset uurimust ühendab soov selgitada ja mõista uute (tehis)keelendite leviku protsessi dünaamilist külge.

\section{Uued sõnad ja nende levik}

\section{1. sihtkomisjon ja ad hoc-komisjon}

Mõistete ad hoc-komisjon või -komitee asemel soovitas võistluse žürii kasutusele võtta eestipärasema sihtkomisjoni või -komitee. Väljavalitud vormi pakkus üksteisest sõltumatult lausa 29 osavõtjat, teiste hulgas ka siinse artikli autor (Erelt 2003). Ajavahemikus 2000-2009 leidus Eesti Päevalehe tekstides mõistet ad hoc antud tähenduses vaid 14 korral (neist 10 korral 2008. aasta sügisel seoses Euroopa Nõukogu Gruusia sõja ad hoc-komiteega) (Kruuse 2008a, 2008b, 2008c), terminit sihtkomitee leidus aga kümne aasta jooksul kõigest ühel korral ja sedagi sõnavõistlusega seotud artiklis (EPL 2002). Sõna esinemissagedus tekstides on põhjalikumaks analüüsiks liiga madal.

\section{2. üleilmastumine ja globaliseerumine}

Sõna globaliseerumine asemele pakuti võistlusel sõna üleilmastumine, samuti soovitati keelendi globaliseeruma asemel kasutada uudisvormi üleilmastuma. Uut vormi pakuti 14 korral (Erelt 2003). Nii uue kui ka vana vormi esinemine korpuses on sage, kümne vaadeldud aasta jooksul esines sõne ${ }^{2}$ globaliseerkokku 1032 ja sõne üleilmastu- kokku 375 korral.

\footnotetext{
${ }^{2}$ Artiklis kasutatakse terminit sõne läbivalt selle informaatikast tuntud tähenduses 'tervikuna käsitletav märgijada'.
} 

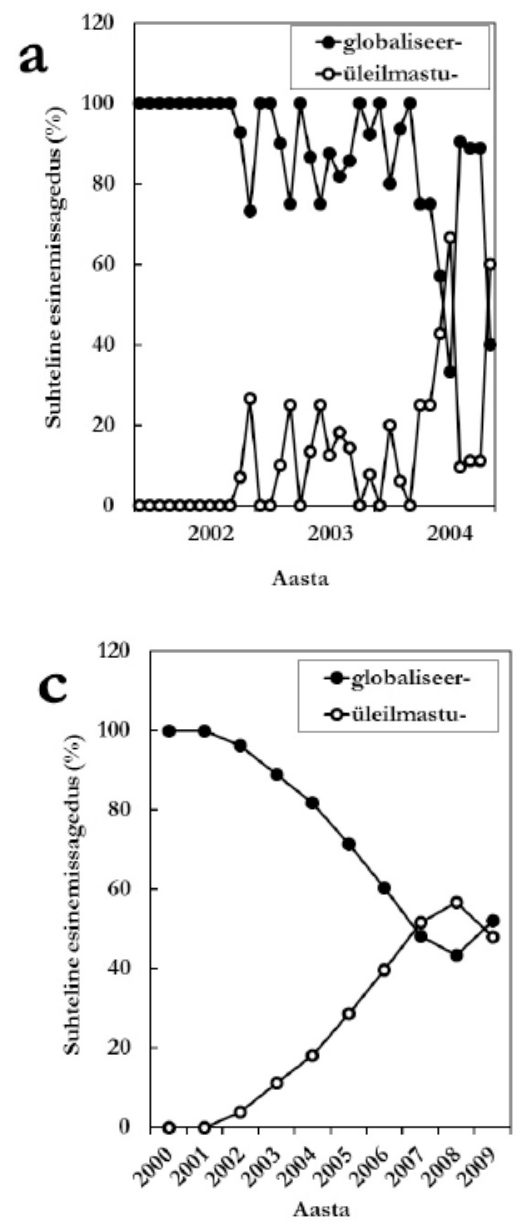

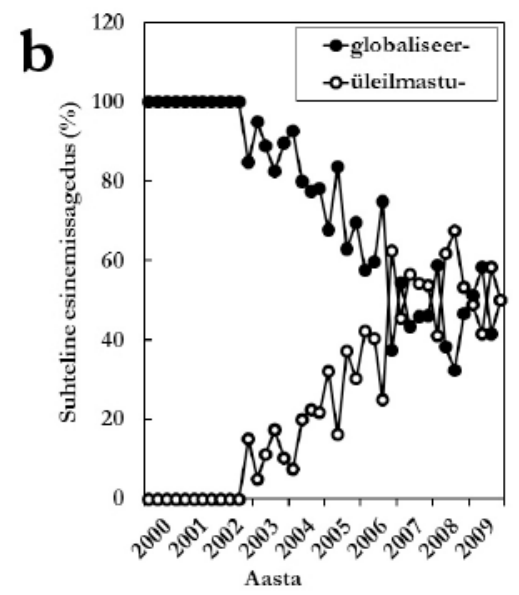

$\mathrm{J}$ o o n i s 2. Sõnede globaliseer- ja üleilmastu- kasutamise suhteline sagedus korpuses: a) aastate 2002-2004 andmed kuude lõikes, b) aastate 2000-2009 andmed kvartalite lõikes, c) 2000-2009 andmed aastate lõikes. Sajaprotsendisele kasutusele vastas 2000 . aastal 145 , 2001. aastal 291, 2002. aastal 134, 2003. aastal 99, 2004. aastal 121, 2005. aastal 185, 2006. aastal 131, 2007. aastal 203, 2008. aastal 120 ja 2009. aastal 123 esinemust.

Enne põhjalikumat analüüsi on oluline küsida, mis on kõige sobivam ajavahemik vaadeldavate muutuste kirjeldamiseks. Kas muutusi sõnakasutuses võib näha juba kuude plaanis või peab uurima pikemaid ajavahemikke? Püstitatud küsimusele püüab vastata joonis 2 . Joonisel $2 \mathrm{a}$ on tüvede globaliseerja üleilmastu- suhteline kasutus aastatel 2002-2004 näidatud kuude lõikes. Sõnavõistluse tulemused avalikustati 25 . novembril 2002. Sama aasta detsembriks on Eesti Päevalehe tekstides juba enam kui iga viies globaliseerumine asendunud üleilmastumisega. Järgneval kahel kuul ei kasutata uut vormi aga üldse, samal ajal kui globaliseer- esineb sama perioodi tekstides kümnel korral. On selge, et korpuse kronoloogiline tihedus ei ole piisav võimaldamaks sõnade leviku uurimist kuuajalise täpsusega.

Järgmisena uuriti võistlevate vormide kasutust kvartalite (joonis 2b) ja aastate (joonis 2c) lõikes. Kvartalite kaupa esitatud kasutuskõverad on samuti mürarikkad: 2005. aasta esimeses kvartalis moodustas sõne üleilmastukogukasutusest pea kolmandiku, kuid teises kvartalis langes selle suhteline sagedus $16 \%$-ni. Niisugused järsud muutused on suure tõenäosusega korpuse ebapiisavast mahust tingitud moonutused. Seega leiti, et sellise kronoloogilise tihedusega korpuse korral annab kõige objektiivsema pildi keelekasutusest andmete esitamine aastate lõikes. 


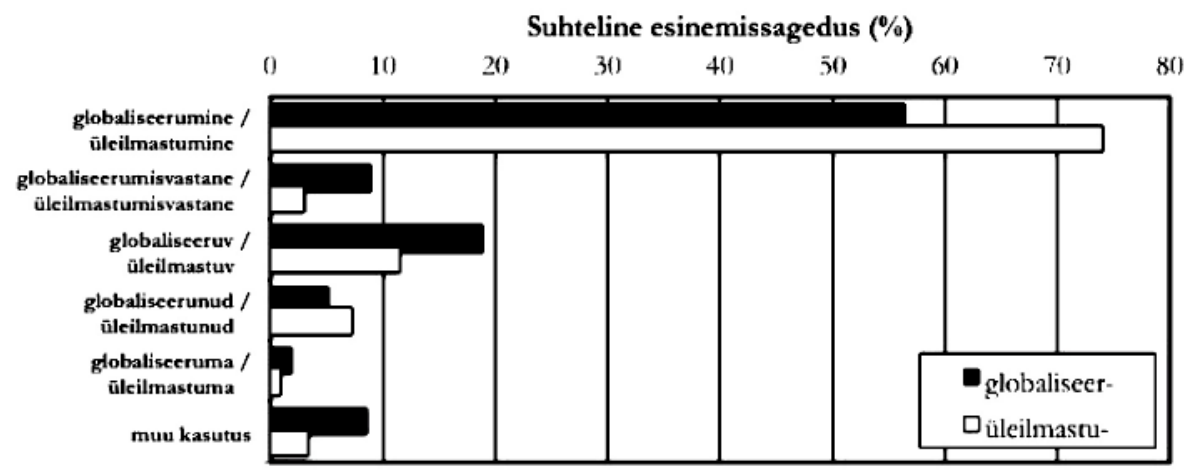

J o o $\mathrm{n}$ i s 3. Sõnede globaliseer- ja üleilmastu- kasutamine konkreetsete vormidena aastatel 2007-2009. Kokku esines vormi globaliseer- vaadeldud perioodil 211 ja vormi üleilmastu- 235 korral.

Nagu joonistelt näha, on uus vorm üleilmastu- väga hästi ajakirjanduse poolt omaks võetud, selle kasutus on alates sõnavõistluse tulemuste väljapakkumisest pidevalt kasvanud (kui mitte arvestada viimast, 2009. aastat). Üleminek uuele vormile on olnud sujuv, vormi levik järgib peaaegu ideaalilähedaselt Rogersi poolt väljapakutud levikuskeemi (vrd joonist 1a ja joonist 2c). Uuenduste leviku teooriast lähtuvalt võib öelda, et sõna leviku esimene faas, kus uudissõna suhteline kasutus moodustab alla 2,5\% kõikidest esinemustest, kestis üleilmastu- puhul kõigest paar kuud. Teine faas, kus uudiskasutus moodustab kokku kuni 16 \% kogukasutusest, saavutati 2004. aastaks ning „varane enamus" oli sõna omaks võtnud 2007. aastaks, kui tüve üleilmastu- kasutus oli esmakordselt kõrgem sõne globaliseer- kasutusest. Aastatel 2008-2009 uue sõna levik pidurdus ning sellest tulenevalt hälbib sõnaleviku graafik vastava veafunktsiooni graafikust. Kui aastal 2008 moodustas uus vorm $57 \%$, siis aastal 2009 vaid $48 \%$ kogukasutusest. Muudatuse põhjuste väljaselgitamine ei kuulu küll siinse uurimuse eesmärkide hulka, kuid võib spekuleerida, et vähemalt osaliselt võib põhjuseks olla muutunud majandusolukord. Mitu aastal 2009 ilmunud artiklit juhivad tähelepanu üleilmastumise lõppemisele või pöördumisele (vt nt Salu 2009; Kaljuvee 2009; Neivelt 2009; Kressa 2009). Hüpoteesi toetab ka hiljutine uuring, kus viidatakse seostele ajakirjanike keelekasutuse ja majandustsüklite muutumise vahel (Gerow, Keane 2011).

Lisaks erinevate tüvede suhtelise kasutuse puhtmatemaatilisele kirjeldamisele on huvitav vaadelda ka nimetatud sõnade kasutuse tähenduslikku aspekti. Uue sõna kasutuselevõtuga võib kaasneda tähendusnihe, samuti võib üks tüvi jääda eelistatuks teatud sõnatarvitusjuhtudes. Joonisel 3 on ära toodud sõnede globaliseer- ja üleilmastu- esinemine sagedastes kasutusvormides aastatel 2007-2009, kui nende esinemissagedus korpuses oli peaaegu võrdne.

Mõlema sõne puhul domineerivad sõnavõistluselgi kasutatud vormid globaliseerumine ja üleilmastumine, mis moodustavad vastavalt $56 \%$ ja $74 \%$ nende kogutarvitusest. Põnevam on vormide globaliseerumisvastane ja üleilmastumisvastane kasutus: esimest vormi leidub vaadeldud perioodil 19 kor- 
da (9 \% kogukasutusest), kuid alternatiivvormi üleilmastumisvastane kõigest 7 korda (3\% kogukasutusest). Tähenduse 'ülemaailmse ühtlustumise vastane' edasiandmiseks kasutasid ajakirjanikud vormi globaliseerumisvastane seega kolm korda tõenäolisemalt kui väljapakutud uudisvormi.

Kui sõne globaliseer- kogukasutusest moodustas vorm globaliseeruv [enamasti kivistunud väljendis (tänapäeva) globaliseeruv maailm] lausa $19 \%$, siis tüve üleilmastu- kogukasutuses mängib vorm üleilmastuv peaaegu kaks korda väiksemat rolli. nud-kesksõna järgib seevastu vastupidist jaotust: üleilmastunud (maailma) eelistatakse globaliseerunud (maailmale). Muudest kasutustest tasub esile tõsta vormi deglobaliseerumine (Kressa 2009), millel sobiv uudisvaste puudub. Korpuses leidus ka fraas globaliseeriv maailm (Kressa 2008), mille uudisvaste on üleilmastav maailm.

Uuring näitas, et ajakirjanikud kasutavad tavaliselt artiklisiseselt kas läbivalt uut või läbivalt vana tüve. Toodud andmete põhjal ei saa otsustada, kas vana vormi kasutamise põhjuseks oli autorite teadlik eelistus (autor on uudisvormist teadlik, kuid eelistab seda mitte kasutada) või teadmatus. Leidus siiski ka olukordi, kus globaliseer- ja üleilmastu- esinesid ühes ja samas artiklis, isegi ühes ja samas lauses. Selline kasutus viitab juba kindlasti autori teadlikule sõnavalikule.

Siinkohal tuleb märkida, et 1999. aasta õigekeelsussõnaraamatus globaliseerumise kõrvale pakutud vormi maailmastumine (vt Erelt 2003) kasutus oli madal juba enne sõnavõistlust (viis või vähem esinemist aastas), sõna kasutus vähenes aga nullilähedaseks pärast sõnavõistluselt leitud suupärasema vormi väljakuulutamist.

\section{3. lõimumine ja integratsioon}

Sõna integratsioon asemel soovitas žürii kasutada Ain Kaalepi väljapakutud vormi lõimimine või lõiming. Samuti pakuti samatüvelisi verbe lõimima ja lõimuma sõnade integreerima ja integreeruma vasteteks (Erelt 2003). Lõimumistemaatika on Eesti ajakirjanduses populaarne teema, seetõttu on nii uue kui ka vana vormi kasutussagedus absoluutarvudes väga kõrge. Vahemikus 2000-2009 esines sõna integratsioon (sh käändevormides ja liitsõnades) kokku 3851 ja tüve lõimu- 590 korral. Lisaks uuriti ka tüve lõimi- kasutust, mida esines kokku 176 korral. $^{3}$ On oluline märkida, et siinsesse uurimusse ei kaasatud vorme integreeruma, integreerima, integreeritud jne kõrge kasutussageduse ja matemaatilise taustaga sünonüümide tõttu.

Sarnaselt sõnaga üleilmastumine on ka lõimu- ja lõimi-tüvelised vormid ajakirjanduses hästi omaks võetud. Uute sõnade leviku kõver (joonis 4) erineb oma kujult aga märgatavalt sõna üleilmastumine leviku kõverast. Uudisvor-

\footnotetext{
${ }^{3}$ Kulturoomika aspektist lähtudes (vt Michel jt 2011) on huvitav märkida, et vormide esinemissagedus kõigub aastate lõikes, aga ka aastasiseselt väga tugevalt. Kui 2001. aastal esines kas sõna integratsioon või tüvesid lõimu-/lõimi- korpuses kokku 936 korral (kasutussagedus 6,6 korda 100000 sõna kohta), siis 2003. aastal vaid 288 korral (3,6 korda 100000 sõna kohta). Lõimumisprobleemid leidsid taas aktiivsemat kajastust 2007. aasta valimiste ja sama aasta aprillis toimunud rahutuste taustal, mistõttu suurenes kasutus ligi 800 esinemiseni aastas (17,2 korda 100000 sõna kohta). Aastatel 2004-2007 saavutas nende vormide esinemine oma maksimumi alati maikuus, tihti tõusis kasutussagedus sama aasta aprilliga võrreldes lausa mitu korda. Arvutustes on kasutatud korpuse mahtu antud aastatel: 2001. aasta Eesti Päevalehe tekstid koosnevad umbes 14247000 sõnast, 2003. aasta tekstid 7938000 sõnast, 2007. aasta tekstid 4604000 sõnast.
} 


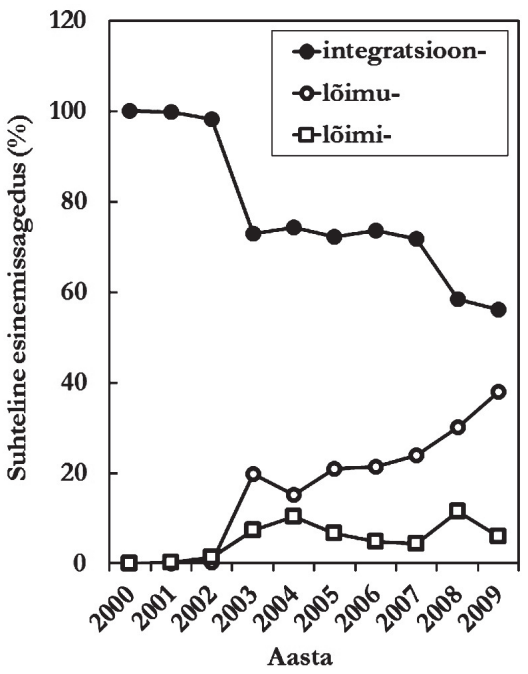

J o o n i s 4. Keeleüksuste integratsioon, lõimu- ja lõimi- kasutamise suhteline sagedus korpuses aastatel 2000-2009. Sajaprotsendisele kasutusele vastas 2000. aastal 751, 2001. aastal 936, 2002. aastal 480, 2003. aastal 288, 2004. aastal 316 , 2005. aastal 253, 2006. aastal 224, 2007. aastal 792, 2008. aastal 322 ja 2009. aastal 255 esinemust.

mide kasutus kasvas kõigepealt hüppeliselt: kõigest aasta pärast sõnavõistluse tulemuste väljakuulutamist oli sõna integratsioon suhteline esinemus vähenenud 70 \%-ni. Järgmisel neljal aastal püsis vana vormi suhteline kasutussagedus samal tasemel - uuenduse levik pidurdus. Leviku aeglustumise põhjuseks võib pidada aastatel 2002-2007 aset leidnud olulist nihet uudistüvede kasutuses. Kui sõnavõistlusele järgnenud esimesel paaril kuul (2002. aasta novembris ja detsembris) moodustas tüve lõimi-kasutus ligi $90 \%$ tüvede lõimu- ja lõimi- summaarsest kasutusest, siis 2007. aastaks oli lõimi- osakaal vähenenud $15 \%$-ni. Jooniselt 4 selgub, et aastatel 2004-2007 toimus lõimutüveliste sõnade kasutuse kasv eelkõige lõimi-tüveliste sõnade arvelt.

Olukorda, kus keelekasutajad leiavad väljapakutud uuendusele esialgsest teistsuguse rakenduse või kus uuenduse levik hoogustub alles pärast selle märkimisväärset teisendumist kasutuses, nimetatakse Rogersi teooria järgi uuenduse taasleiutamiseks (ingl re-invention). Rogersi järgi on taasleiutamine oluline osa uuenduse omaksvõtmise protsessist. On postuleeritud, et taasleiutamise võimalikkus ja lubatus soodustab uuenduste levikut (Rogers 2003: 180). Ka siinsel juhul on põhjust arvata, et uudissõnade levik oleks olnud märksa aeglasem, kui keelekasutajate seas poleks toimunud nihet žürii poolt väljapakutud vormide lõimimine ja lõiming juurest vormi lõimumine poole.

Uudiskeelendite levikut vaadeldi ka tähenduslikust aspektist. Vormide kasutus on kokkuvõtvalt esitatud joonisel 5. Kõigi kolme uuritud sõne puhul moodustas nimisõnaline vorm (integratsioon, lõimumine ja lõimimine) valdava osa kasutusest (vastavalt $56 \%, 62 \%$ ja $41 \%$ ). Seevastu esialgne väljapakutud vorm lõiming ei ole kasutusse läinud (esinemused vaid sõnavõistluse tulemusi kajastavates artiklites). On huvitav, et tüve lõimi- korral moodustas verbivorm lõimima ligi kolmandiku kogukasutusest (55 juhtu), samal ajal kui tüve 


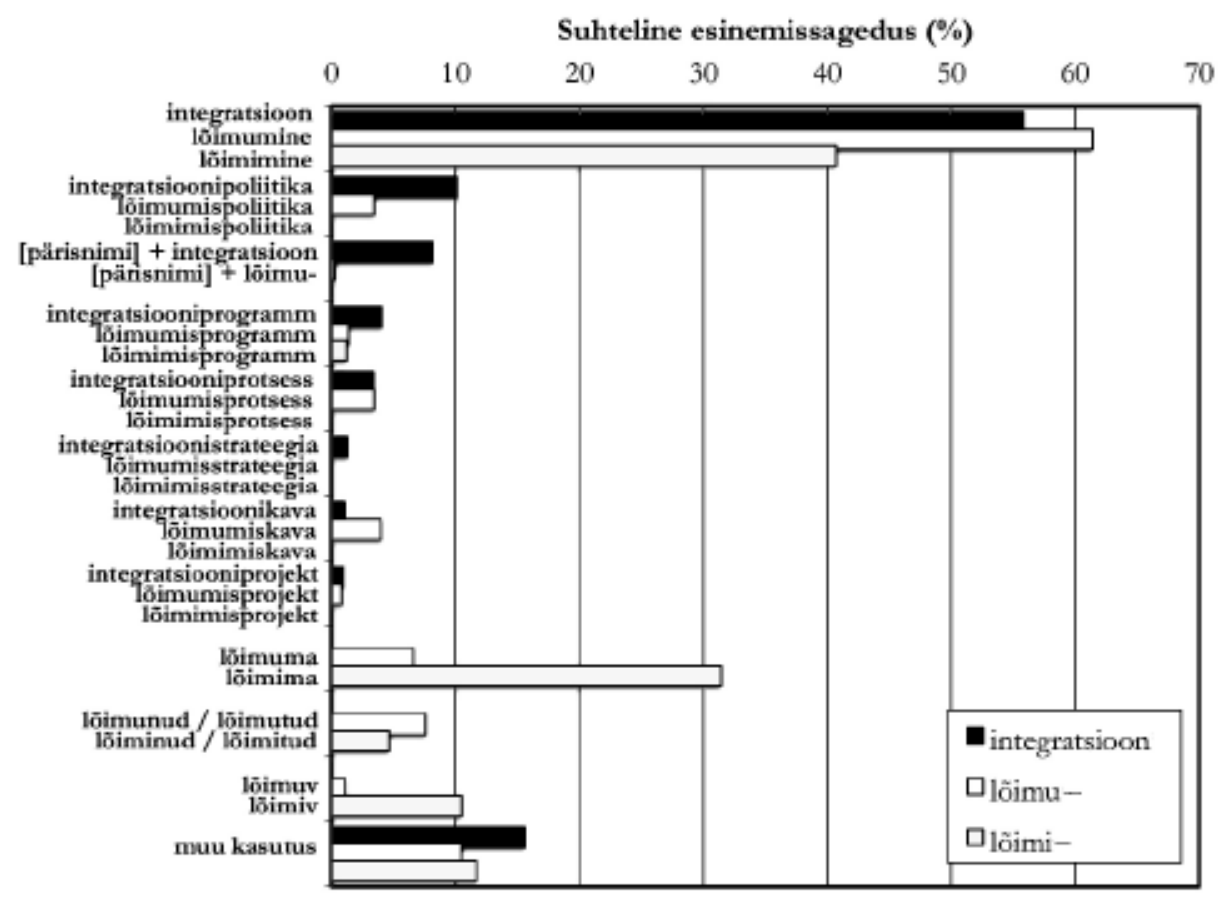

J o o n i s 5. Keeleüksused integratsioon, lõimu- ja lõimi-konkreetsete vormidena aastatel 2007-2009. Kokku esines sõna integratsioon vaadeldud perioodil 3851, tüve lõimu- 590 ja tüve lõimi- 176 korral.

lõimu- kasutusest moodustas vastav verbivorm vaid $7 \%$ (41 juhtu). Sarnane on olukord $v$-kesksõna kasutuses. Vaadeldud ajaperioodil eelistasid ajaleheartiklite autorid lõimumisteemalisele poliitikale viidates kindlalt vananenud vormi integratsioonipoliitika uudisvormile lõimumispoliitika; vormi lõimimispoliitika ei esinenud tekstides kordagi. Sõna integratsioon kasutatakse eelistatult liitsõnas koos põhisõnaga -programm, seevastu tüvi lõimu- esineb samas tähenduses pigem koos põhisõnaga -kava (lõimumiskava). Pärisnimelises kasutuses domineerivad asutuste ja organisatsioonide nimed, enim integratsiooni sihtasutus (ametliku nimega Mitte-eestlaste Integratsiooni sihtasutus). Uudisvormide kasutus pärisnimedes oli väga madal, uusi vorme kasutati eelkõige välismaiste lõimumisega seotud asutuste nimede tõlkimisel (nt Euroopa ja Euro-Atlandi lõimumise koordinatsioonibüroo). Kodumaiste asutuste nimedes uudisvorme peaaegu ei esinenud. Muudest kasutustest väärib äramärkimist Euroopa Liiduga lõimumist iseloomustav eurolõimumine (Owen 2007) ja tegijanimi lõimija (Kaljuvee 2008b). 


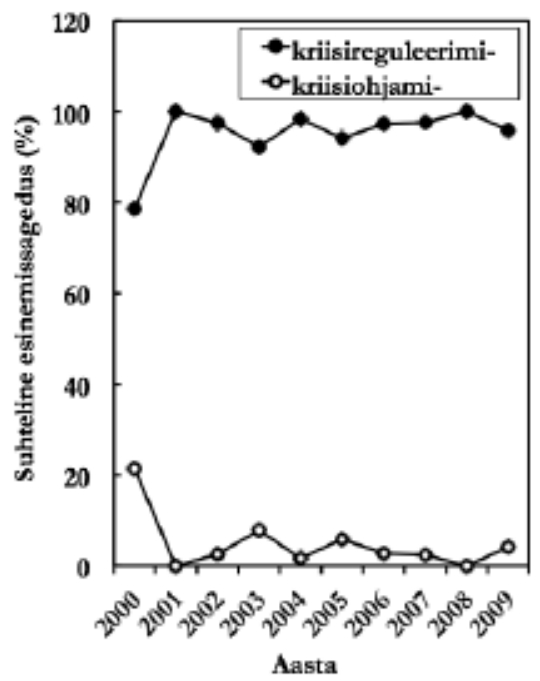

J o o n i s 6. Sõnede kriisireguleerimi- ja kriisiohjami- kasutamise suhteline sagedus korpuses aastatel 2000-2009. Sajaprotsendisele kasutusele vastas 2000. aastal 14,2001 . aastal 16,2002 . aastal 42,2003 . aastal 51, 2004. aastal 61,2005 . aastal 86,2006 . aastal 73, 2007. aastal 41, 2008. aastal 28 ja 2009. aastal 24 esinemust.

\section{4. kriisiohjamine ja kriisireguleerimine}

Sõnad kriisikorraldus, -ohjeldus ja -reguleerimine soovitati sõnavõistluse tulemusena asendada vormiga kriisiohjamine. Uut vormi pakkus iseseisvalt kaheksa osalejat (Erelt 2003). Kokku esines sõna kriisireguleerimine korpuses aastatel 2000-2009 kokku 414 korral, sõna kriisikorraldus kasutati Eesti Päevalehe tekstides samas ajavahemikus väljaspool sõnavõistluse konteksti vaid ühel korral, vormi kriisiohjeldus aga mitte kordagi. Uudisvormi kriisiohjamine esines vaid 18 korral. Uudissõna leviku kõver on toodud joonisel 6 . On selge, et uudisvorm ei ole juurdunud. Seda kinnitab ka tõsiasi, et mitmed ministeeriumid ja kohalikud omavalitsused on pärast sõnavõistluse toimumist rajanud kriisireguleerimise (ja mitte kriisiohjamise) üksusi ja osakondi, näitena võib tuua siseministeeriumi pääste- ja kriisireguleerimispoliitika osakonna (loodud 2006), majandus- ja kommunikatsiooniministeeriumi kriisireguleerimise osakonna (loodud 2007), politseiameti kriisireguleerimise üksuse (loodud 2009) ja Tallinna kriisikomisjoni kriisireguleerimismeeskonna (loodud 2010).

On märkimisväärne, et vorm, mis läks ametlikku kasutusse alles 2002. aastal, esines kolmel korral 2000. aasta Eesti Päevalehe artiklites (ETA 2000, BNS 2000) samas tähenduses.

\section{5. täisleppimatus ja nulltolerants}

Sõna nulltolerants kõrvale pakkus sõnavõistluse žürii eestipärasemat vormi täisleppimatus. Uut sõna soovitas kaks osalejat (Erelt 2003). Täisleppimatusetemaatika ei ole vaadeldud ajavahemikus ajakirjanduses laialdast kajastust leidnud: sõna nulltolerants (ka null-tolerants) esines korpuses aastatel 2000- 


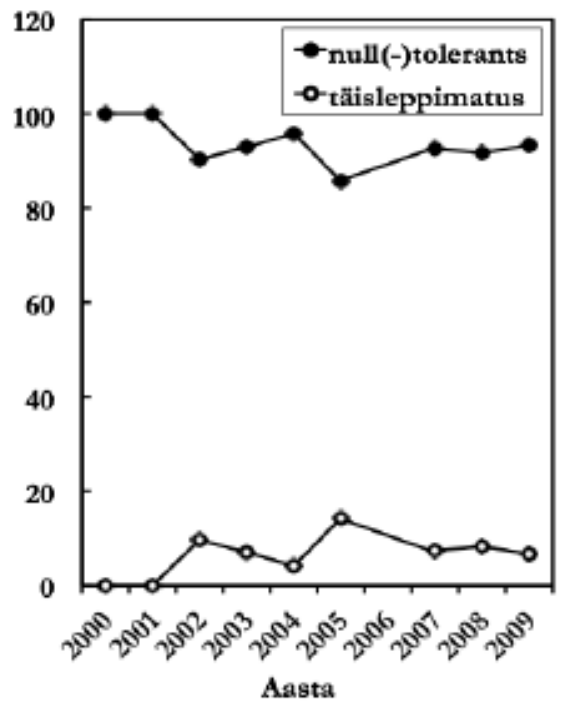

J o o n i s 7. Sõnade null(-)tolerants ja täisleppimatus kasutamise suhteline sagedus korpuses aastatel 2000-2009. Sajaprotsendisele kasutusele vastas 2000. aastal 10,2001 . aastal 12,2002 . aastal 62,2003 . aastal 71,2004 . aastal 24,2005 . aastal 21, 2007. aastal 27, 2008. aastal 12 ja 2009. aastal 15 esinemust. 2006. aastal esines uuritavaid vorme korpuses kokku vaid kolmel korral, mistõttu pole selle aasta andmed joonisel esitatud.

2009 kokku 225 korral, uudisvormi aga vaid 22 korral. Kuigi nii uudis- kui ka võõrapärase vormi kasutussagedus on madal, on esinemusi uudissõna leviku dünaamika uurimiseks siiski piisavalt. Vastav graafik on toodud joonisel 7 . Uus vorm ei ole kasutusse läinud: selle suhteline esinemissagedus jõudis küll 2005. aastaks $15 \%$ piirimaile, viimasel kolmel uuritud aastal aga oli sõna kasutussagedus langenud taas alla kümne protsendi.

Sõnade täisleppimatus ja kriisiohjamine levikut tulevikus ei saa siiski välistada. J. Aaviku keeleuuenduste kasutuseletulekut uurides leidis A. Chalvin, et keelendite levik võib tihti olla viivitatud algusega: näiteks tehissõna meede (loodud 1941) jõudis laiemasse kasutusse alles 30-40 aastat pärast selle väljapakkumist (Chalvin 2011: 499).

\section{6. lähimus ja subsidiaarsus}

Sõna subsidiaarsus asemel soovitas võistluse žürii kasutusele võtta eestipärasemad vormid lähimus või lähimuspõhimõte. Uue vormi pakkus välja Aado Keskpaik (Erelt 2003). Ajavahemikus 2000-2009 leidus Eesti Päevalehe tekstides sõna subsidiaarsus 31 korral, alternatiivvormi lähimus aga kõigest 9 korral. Sõna esinemissagedus ajakirjandustekstides on põhjalikumaks analüüsiks liiga madal.

Vormide subsidiaarsus ja lähimus kasutust erialastes tekstides (Eesti õigusaktides ja Euroopa Liidu õigusaktide tõlgetes) on käsitletud Tallinna Ülikoolis hiljuti valminud magistritöös (Mihkla 2010). Töös on välja toodud, et „Euroopa Komisjoni juhtnöörides vabakutselistele tõlkijatele ei soovitata 


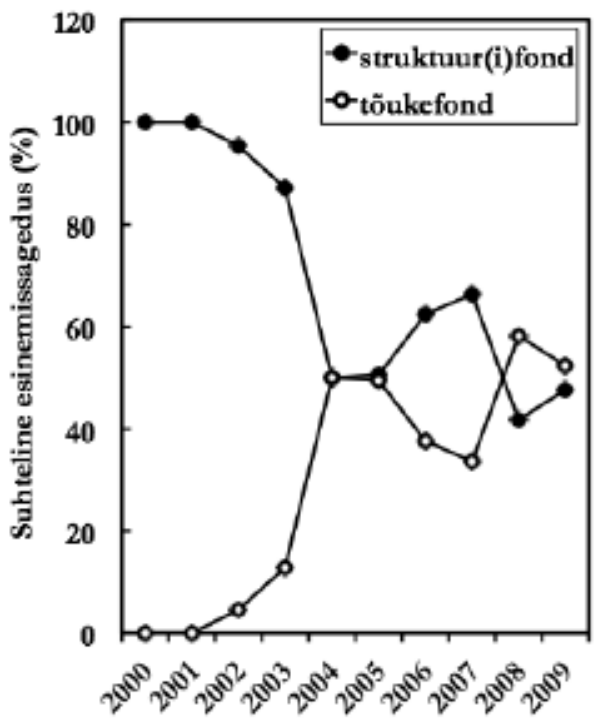

J o o n i s 8. Sõnade struktuur(i)fond ja tõukefond kasutamise suhteline sagedus korpuses aastatel 2000-2009. Sajaprotsendisele kasutusele vastas 2000. aastal 11, 2001. aastal 26, 2002. aastal 65, 2003. aastal 163, 2004. aastal 152, 2005. aastal 180, 2006. aastal 109, 2007. aastal 116, 2008. aastal 146 ja 2009. aastal 126 esinemust.

uut terminit õigusaktides kasutada, kuna tegemist on põhilepingutest pärit mõistega ja nendes lepingutes on see juba tõlgitud subsidiaarsuse põhimõtteks. [...] [T]uleb... lähtuda termini järjepidevusest" (Mihkla 2010: 40). Euroopa Liidu kehtivas õiguses saab ühe termini asendada teisega ainult juhul, kui seni kasutusel olnud termin on muutunud täiesti ebasobivaks, mida aga vormi subsidiaarsus kohta öelda ei saa. Ilma põhjalikuma seletuseta on uudisvorm lähimus tavakodanikele niisama arusaamatu kui subsidiaarsus (Mihkla 2010: 40). Nendest põhjendustest lähtuvalt on uudissõna laialdasem kasutuselevõtt pigem ebatõenäoline.

\section{7. tõukefondid ja struktuurifondid}

Sõna struktuurifondid asemele pakuti võistlusel vormi tõukefondid. Uue termini eeliseid nähti lihtsas lahenduses ja läbinähtavas mõttes: fondide raha eesmärgiks on anda tõuge arengu kiirendamiseks ja mahajäämusest ülesaamiseks. Sõna pakkus kaks osalejat, Eduard Selge ja Silvi Nemvalts (Erelt 2003).

Euroopa Liidu toetuste temaatika on Eesti ajakirjanduses tähtsal kohal, seetõttu on nii uue kui ka vana vormi kasutussagedus absoluutarvudes küllaltki kõrge. Vahemikus 2000-2009 esines sõna struktuurifond Eesti Päevalehe tekstides kokku 604 ja sõna tõukefond 420 korral. Lisaks uuriti ka vormi struktuurfond kasutust, mida esines kokku 70 korral. Uudissõna leviku kõver on toodud joonisel 8.

Jooniselt selgub, et uudisvorm tõukefond levis aastatel 2002-2004 lausa hämmastava kiirusega. E. Rogersi väljapakutud uuenduste leviku mudeli jär- 
gi olid kõige uuenduslikumad keelekasutajad sõna omaks võtnud juba 2002. aasta lõpuks (kui vormi tõukefond osatähtsus kogukasutuses oli 4,6 \%). 2004. aasta korpuses aga leidus uudissõna juba võõrapärase vormiga võrdselt - mõlemat 76 korral. Uue vormi sedavõrd kiire leviku põhjal võinuks 2004. aastal ennustada, et 2007. aastaks moodustab väljapakutud vorm juba enam kui $95 \%$ kogukasutusest. Ometi ei ole nii läinud: uudisvormi levik on pidurdunud ja püsis veel 2009. aastalgi $50 \%$ piirimail.

Vihjeid sellise arenguloo põhjuste kohta leiab Eesti Päevalehe 2005. aasta 14. mail ilmunud artiklist (Makko 2005): „Lehetoimetuste ja riigiasutuste vahel tekitavad tüli tõukefondid, mida 2002. a toimunud sõnavõistluse žürii on soovitanud kasutada struktuurifondide asemel. Sel teemal EPL-i toimetajatele kirjutanud rahandusministeeriumi nõunik Kristi Jõesaar tõi põhjenduseks: „Inimesed on aru saanud, et tõukefondid erinevad struktuurifondidest ning toetust saab taotleda mõlema raames, aga erinevatel alustel." Kuna seadustikus räägitakse struktuurifondidest, soovitas ta sama teha ajalehes. Meie jälle ei taha tõukefondidest loobuda." Õigusaktides ja Euroopa Liidu seaduste tõlgetes uudisvormi terminoloogilise järjepidevuse huvides ei kasutata (Mihkla 2010: 37; vt ka Mund 2007). Uute vormide kasutamine oli Riigikogus arutlusel 2005. aastal struktuuritoetuse seaduse eelnõu lugemisel. Leiti, et „nii laialt kasutatava termini muutmine oleks äärmiselt segadusttekitav” ning et „terminit tõukefondid ei ole mõistlik kasutusele võtta sõna tõuke negatiivse varjundi tõttu" (Mihkla 2010: 39).

\section{8. rakkerühm ja task force}

Ingliskeelse task force vasteks pakuti 2002. aasta võistlusel sõnu rakkerühm või rakkejõud, mille käis välja Endel Valdas (Erelt 2003). Sõnade esinemissagedus on täpsemaks analüüsiks liiga madal: ajavahemikul 2000-2009 esines keelendit task force Eesti Päevalehe tekstides kokku 25, üksust rakkerühm 21 ja rakkejõud vaid 3 korral.

\section{9. mestimine ja twinning}

Ingliskeelse tsitaatsõna twinning asemel soovitati kasutada suupärasemaid mõisteid mestimine ja mesting, mille autoriks oli Kadri Roos (Erelt 2003). Vaadeldud sõnu ei esinenud koostatud korpuses piisavalt, et võimaldada põhjalikumat analüüsi: vormi twinning leidus ajakirjandustekstides 22 , sõne mestimviiel korral. Vormi mesting korpuses ei esinenud. Erinevalt sõnadest tõukefondid ja lähimus on uus vorm aga Euroopa Liidu juriidiliste tekstide tõlgetes omaks võetud (Mihkla 2010: 39).

\section{0. vabaühendused ja valitsusvälised organisatsioonid}

Valitsusväliseid organisatsioone soovitas žürii edaspidi nimetada vabaühendusteks. Uut vormi pakkus kümme osalejat (Erelt 2003). Korpuseotsingus rakendati otsinguna vorme valitsusväli-, valitsusteväli-, valitsuseväli- (leidmaks fraase valitsusvälised organisatsioonid, valitsustevälised organisatsioonid ja valitsusevälised organisatsioonid). Päringu tulemuste põhjal otsustati analüüsi lisada ka fraas valitsusvälised ühendused. Kõiki neid tähistatakse 


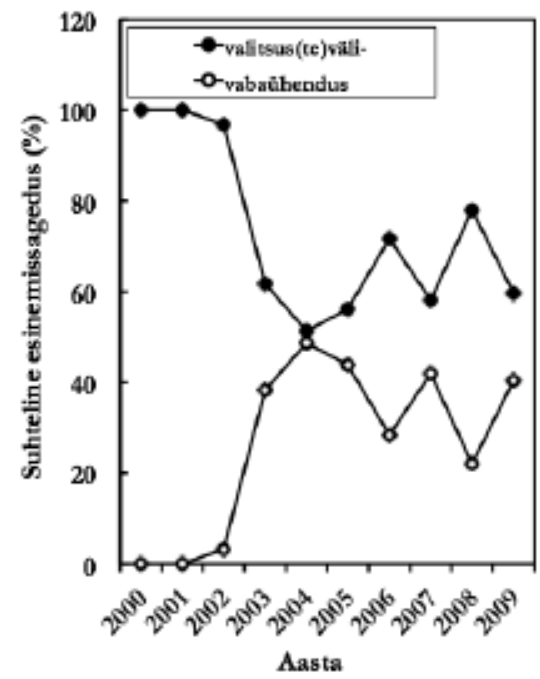

J o o n is 9. Vormide valitsus(te)väli- ja vabaühendus kasutamise suhteline sagedus korpuses aastatel 2000-2009. Sajaprotsendisele kasutusele vastas 2000. aastal 78,2001 . aastal 79,2002 . aastal 31,2003 . aastal 47,2004 . aastal 39, 2005. aastal 57,2006 . aastal 74, 2007. aastal 105, 2008. aastal 59 ja 2009. aastal 52 esinemust.

järgnevas tekstis kokkuvõtvalt vormiga valitsus(te)väli-. Kokku esines vormi valitsus(te)väli- vaadeldud aastatel korpuses 459 korral, vormi vabaühendus aga 162 korral. Uudisvormi levikut kirjeldav graafik on ära toodud joonisel 9.

Uudissõna vabaühendus levik on dünaamikalt väga sarnane sõna tõukefondid levikuga. Aastatel 2002-2004 levis uudisvorm ajakirjanduses kiiresti, jõudes $50 \%$ piirimaile, edasine levik on aga pidurdunud. Uue vormi kasutuselevõttu soodustab tõsiasi, et sõnavõistluse järgselt võttis Eesti vabaühinguid koondav Eesti Mittetulundusühingute ja Sihtasutuste Liit endale uueks nimeks Vabaühenduse Liit EMSL. Kui 2004. aastal loodi vabaühenduste toetusi haldav organisatsioon, sai selle nimeks Vabaühenduste Fond.

\section{1. ôigustik ja acquis}

Euroopa Liidu õigusaktides tihti esineva sõna (ühenduse) acquis asemele leiti termin (ühenduse) öigustik. Väljavalitud uudissõna pakuti kaheksal korral (Erelt 2003). Sõna kasutussagedus korpuses on küllaltki madal: vormi acquis esines Eesti Päevalehe tekstides ajavahemikul 2000-2009 57 korral, keelendit õigustik aga sama ajavahemiku jooksul 27 korral. Uudissõna leviku dünaamiline analüüs on siiski võimalik (joonis 10), kuigi 2004., 2008. ja 2009. aasta andmed tuli jooniselt esinemuste vähese arvu tõttu välja jätta.

Eesti Päevalehe tekstide analüüsi põhjal võib väita, et uudisvorm õigustik on keeles küllaltki hästi juurdunud ja tsitaatvormi acquis kasutus on sõnavõistluse järgselt aasta-aastalt järjest vähenenud. ${ }^{4}$

\footnotetext{
${ }^{4}$ Erandiks on siin 2007. aasta, kus vana vormi kasutati rohkem kui 2006. aastal. Uuritud
} 


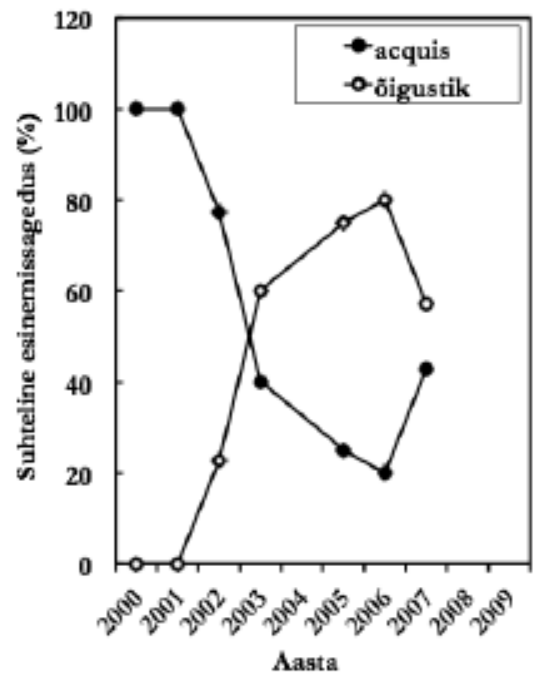

J o o n is 10. Sõnade acquis ja õigustik kasutamise suhteline sagedus korpuses aastatel 2000-2009. Sajaprotsendisele kasutusele vastas 2000. aastal 15, 2001. aastal 13, 2002. aastal 22, 2003. aastal 10, 2005. aastal 4, 2006. aastal 5 ja 2007 . aastal 7 esinemust. 2004., 2008. ja 2009. aastal tekstides leidus vastavalt vaid 3, 2 ja 3 lauset, kus vähemalt üks antud vormidest esines, mistõttu jäeti nende aastate andmed graafikust välja.

\section{Uudiskeelendid sotsiolingvistilises kontekstis}

Ülaltoodud tulemused on huvitav asetada laiemasse sotsiolingvistilisse raamistikku, et leida vastuseid küsimustele, nagu

- $\quad$ kas sõnade leviku graafikute põhjal on võimalik teha järeldusi leviku sotsiaalsete aspektide kohta?

- $\quad$ kes on kõige uuenduslikumad keelekasutajad ehk novaatorid?

- miks ei ole uute vormide levik sirgjooneline, s.t miks jäävad paljud uudiskeelendid oma levikus toppama ega tõrju vana vormi välja?

Sellised küsimused on olnud paljude sotsiolingvistiliste uuringute tulipunktis (vt nt Weinreich, Labov, Herzog 1968; Labov 1972a; 1972b; Milroy, Milroy 1985; Chambers 2002; aga ka Ehala 2011).

Klassikalise käsitluse järgi on keeleliste uuenduste levik ja seda mõjutavad tegurid tihedalt seotud identiteedi mõistega. Keel on vahend, mille abil selle kasutajad seostavad (või soovivad seostada) end kindlate, nende silmis prestiižsete ühiskonnagruppidega. Keeleuuendust mõjutavate tegurite hulgast on esile tõstetud kasutajate sugu ja vanust, aga ka nende ühiskondlikku staatust ja seotust teiste gruppidega (Luraghi 2010: 364-365). Uurides keelekasutust Belfasti eri linnaosades, leidsid James Milroy ja Lesley Milroy, et teatud foneetilisi uuendusi, nagu kõrgenev ja pikenev / $/$ / (sõnades bed ja bet), soosivad vormide esinemissagedus on siiski nii madal, et andmete põhjal ei saa teha järeldust selle hüppe statistilise olulisuse kohta. 

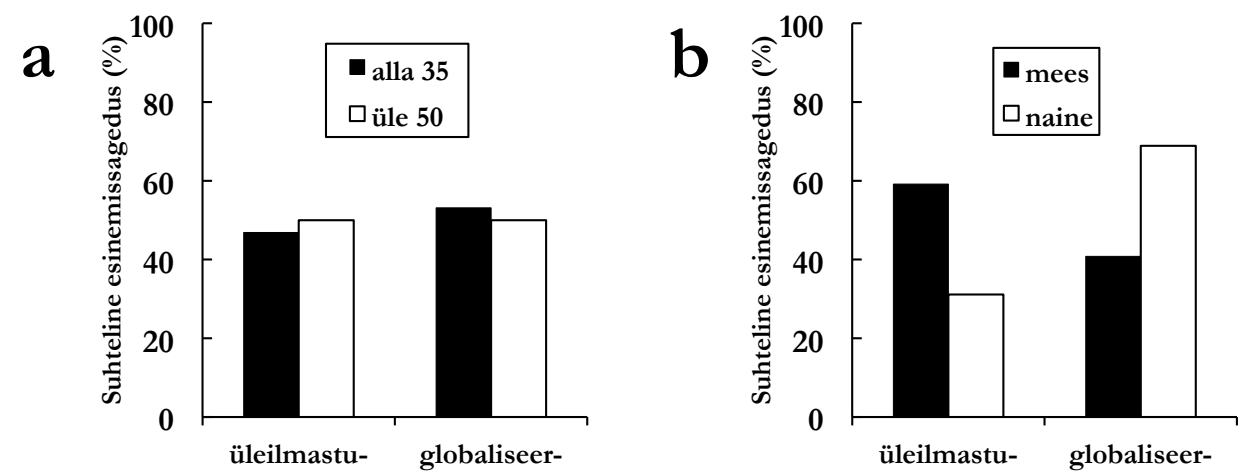

J o o n i s 11. Sõnede üleilmastu- ja globaliseer- esinemise jagunemine 2007. aasta korpuseandmete põhjal: a) vanusegrupiti, b) kasutajate soo põhjal.

ennekõike noored katoliikliku linnaosa naised, samal ajal kui teisi uuendusi, näiteks tahasuunduvat /a/-d (sõnades that, wrap jne), hoopis vanemaealised protestantliku taustaga mehed (Milroy, Milroy 1985: 350-359). Analüüsides New Yorgi Harlemi linnaosa noortegängide keelekasutust, avastas William Labov, et üksikud kõrge grupisisese staatusega võtmeisikud võisid olulisel määral mõjutada kogu grupi keelekasutust. Seevastu grupi tuumaga nõrgalt seotud isikud, keda kutsuti Harlemis „luhvtideks” (ingl lame), paistsid silma oma teistsuguse keelekasutuse poolest (Labov 1972a: 269).

Sotsiolingvistilistes uurimustes on leitud, et novaatoriteks ja keeleliste uuenduste varajasteks omaksvõtjateks on tihti madalama ühiskondliku staatusega indiviidid, kellel pole uuendust kasutama hakates midagi kaotada (vt nt Rogers 2003: 1-3). Just sotsiaalne prestiiž (täpsemalt selle puudumine) on põhjuseks, miks Peruu väikekülas hakkab riikliku sotsiaaltöötaja ärgitusel vett enne tarvitamist keetma just ühiskondliku heidiku staatuses olev, hiljuti mägikülast sisserännanud perekond, samal ajal kui teised külaelanikud uuenduse hülgavad, ning miks kõrgenevat ja pikenevat/E/-d hakkavad Belfastis esimesena kasutama madalama ühiskondliku staatusega katoliikliku linnaosa naised (Milroy, Milroy 1985: 357). Lisaks on leitud, et uudiskeelendi leviku protsessis esineb tihti perioode, kus kasutajate eelistus kõigub pendlina uue ja vana vormi vahel (Wolfram, Schilling-Estes 2003: 717).

Uudisvormi kasutajate sooline ja vanuseline analüüs on põhimõtteliselt võimalik ka siinse töö andmete põhjal. Üks näide vormide globaliseeru- ja üleilmastu- kasutuse jaotumisest eri kasutajagruppide vahel on toodud joonisel 11. Andmete põhjal võib spekuleerida, et erinevalt J. Milroy ja L. Milroy uurimusest ei ole kasutajate vanus uuritud sõnapaari levikul oluline deskriptor: nii üle 50-aastased kui ka alla 35-aastased kasutasid ajaleheartiklites uudisvormi peaaegu ühe ja sama tõenäosusega (joonis 11a). Kui aga deskriptoriks valida artikli autori sugu, ilmneb, et 2007. aastal kasutasid uudissõnet pigem mehed (meeste kogukasutusest moodustas üleilmastu- $59 \%$ ja globaliseer- $41 \%$ ) ja vana tüve pigem naised (üleilmastu- $31 \%$ ja globaliseer- $69 \%$ ) (joonis 11b). Olgu öeldud, et väljatoodud andmete põhjal on raske teha üldistusi ning korpuseandmete põhjalikumat analüüsi siinses artiklis ei esitata. 


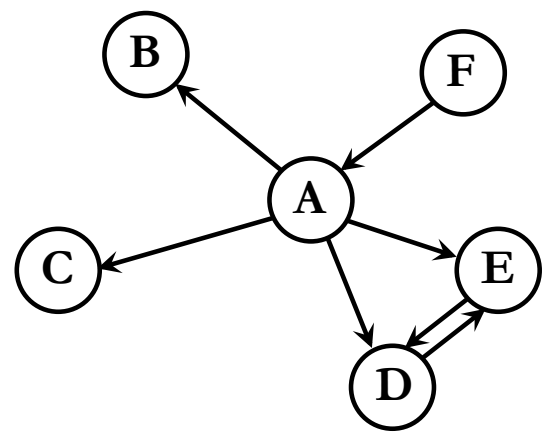

J o o n i s 12. Sotsiaalvõrgustiku struktuuri ja selle liikmete mõjusfääre kirjeldava mudeli lihtsustatud skeem (Fagyal jt 2010: 2066 põhjal).

Keeleliste uuenduste levikut on uuritud ka sotsiaalvõrgustikke kirjeldavate arvutimudelite abil (nt Fagyal jt 2010; Nettle 1999). Kuigi kasutatud mudelid on matemaatiliselt äärmiselt lihtsad, võimaldavad arvutisimulatsioonid teha uuenduste leviku sotsiaalsete mehhanismide kohta üllatavalt kaugeleulatuvaid järeldusi. Olgu siinse uurimuse tulemuste laiemasse konteksti asetamiseks ära toodud ühe mudeli (Fagyal jt 2010) lühikirjeldus ja peamised järeldused.

Mudeli autorid vaatlesid 900-liikmelist sotsiaalvõrgustikku kui samast arvust sõlmpunktidest ning nendevahelistest vektorsidemetest koosnevat süsteemi (vt joonist 12). Sõlmpunktid tähistavad mudelis indiviide, nendevahelised sidemed aga informatsiooni edasikandmiseks vajalikke ühendusi. Joonisel 12 toodud näites võivad keelekasutajat A mõjutada nii B, C, D kui ka E, kuid mitte vastupidi. Kasutajate D ja $E$ vaheline side on kahesuunaline, s.t nad võivad mõlemad kopeerida üksteise keelekasutust. Individuaalse keelekasutaja mõjusfäär on seda suurem, mida suurem on vastavasse sõlmpunkti suunatud sidemete arv. Toodud skeemil on D ja E seega kõige mõjuvõimsamad keelekasutajad. B ja C keelekasutust ei mõjuta aga keegi, kuid nad võivad teatud juhtudel mõjutada teisi enda ümber. Sidemete loomise protseduuri matemaatilist tausta on pikemalt kirjeldatud viidatud artiklis (Fagyal jt 2010: 2065-2066).

Simulatsiooni alguses omistatakse igale sõlmpunktile juhuslikkuse põhimõttel teatud binaarne olek, milleks võib olla näiteks vormi twinning eelistamine vormile mestimine või vastupidi. Igal järgneval ajahetkel valitakse 900 punkti seast juhuslikult üks sõlmpunkt, mis muudab oma olekut, võttes üle keelelise oleku ühelt oma mõjutajalt. Kui valitud sõlmpunktid on ühes ja samas olekus, siis ei muutu protsessi tagajärjel esialgse sõlmpunkti keelekasutuses midagi.

Kasutajatevaheliste sidemete eksisteerimine on keeleuuenduste levikuks üksnes tarvilik, kuid mitte piisav tingimus. On selge, et uuenduste levikul mängib rolli ka nende sidemete tugevus, s.t indiviidide ühiskondlik staatus, prestiiž. Selleks lisati mudelisse tingimus, mille kohaselt sõltub teatud mõjutaja valimise tõenäosus võrdeliselt selle sõlmpunkti mõjusfääri suurusest (sissetulevate sidemete arvust). Nii on tagatud, et suurema mõjusfääriga keelekasutajad (arvamusliidrid) mõjutavad teisi sagedamini kui väikese mõju- 
sfääriga keelekasutajad („luhvtid”), ent samas ei ole ka viimaste mõju teistele täiesti välistatud (Fagyal jt 2010: 2068).

On tähelepanuväärne, et sedavõrd lihtne matemaatiline mudel suudab edukalt jäljendada uuenduste leviku S-kujulist graafikut (joonis 1). Veelgi huvitavamad (ja siinse töö seisukohalt äärmiselt olulised) on aga mudeli autorite märkused selle kohta, millistel juhtudel uuenduste leviku graafik traditsioonilisest S-kujust hälbib. Olukorras, kus sotsiaalvõrgustikus puuduvad selged arvamusliidrid, s.o sõlmpunktid, kes mõjutavad suurt hulka teisi punkte, ei kujune võrgustikus välja selgeid kasutusnorme. Ühe keelendi suhteline kasutussagedus võib küll hetkeks ületada $50 \%$ piiri, kuid seejärel levik pidurdub ja hakkab järsult vähenema. Vaid veidi stabiilsem on olukord sotsiaalvõrgustikus, kus teatud mõjutaja valimise tõenäosus ei ole võrdelises seoses selle sõlmpunkti mõjusfääri suurusega, s.t võrgustikus, kus puudub sotsiaalse prestiiži nähtus. Seevastu võrgustikus, kus puuduvad väikese mõjusfääriga, ent järjekindlad kasutajad, ei ole uuenduste levik üldse võimalik: mõjukad arvamusliidrid suruvad iga väljapakutud uuenduse kiiresti maha. Uuenduste leviku võimaldamiseks ei pea „luhvtide” arv võrgustikus olema kõrge. Piisab, kui 20 sõlmpunkti 900-st (s.o vaid $2 \%$ kogu võrgustikust) käituvad analoogiliselt sõlmpunktidega $\mathrm{B}$ ja $\mathrm{C}$ joonisel 12 . Viimasest katsest järeldub ühtlasi ka tõsiasi, et need, vähemõjukad, kuid järjekindlad keelekasutajad ongi novaatorid (Fagyal jt 2010: 2071-2073).

Eespool toodud sõnapaaride leviku graafikute põhjal võib kirjeldatud mudeli valguses teha oletusi uudissõnade leviku sotsiaalsete mehhanismide kohta. Sõna üleilmastumine ideaalilähedaselt S-kujuline graafik (joonis 2) viitab sellele, et selle sõna levikut toetavad arvamusliidrid ja sõna kasutamine on ühiskonnas prestiižne. Teatavate mööndustega kuuluvad samasse kategooriasse ka sõnad lõimima/lõimuma ja õigustik (joonised 4 ja 10). Uudisvorme täisleppimatus ja kriisireguleerimine seevastu kannavad edasi vaid järjekindlad keeleuuenduse entusiastid, kellel puudub arvamusliidrite tugi (joonised 6 ja 7). Sõnade tõukefond (joonis 8) ja vabaühendus (joonis 9) levik on pidurdunud. Hoolimata sellest, et ka neil uudisvormidel on olemas järjekindel kasutajaskond ning nende levimist toetab osa arvamusliidritest, ei paista uudissõnade kasutamine olevat prestiižne - leidub inimesi, sh mõjuvõimsaid keelekasutajaid (riigiasutused), kes uudisvormide levikut ei soosi. Uuenduse edukaks ja kiireks levikuks peavad aga kõik kolm eespool toodud eeldust olema korraga täidetud.

\section{Kokkuvõte}

Siinse artikli eesmärgiks oli vaadelda süstemaatiliselt 2002. aasta sõnavõistlusel väljapakutud uudiskeelendite levikut Eesti ajakirjandustekstides. Sõnavõistlus on keelekorralduse vaatepunktist ainulaadne vahend, mille uurimine aitab mõista keelendite leviku protsessi dünaamikat ja seaduspärasusi. Töö tulemused võib nüüd, veidi enam kui 10 aastat pärast uute keelendite väljapakkumist, kokku võtta järgmiselt: 
1. Üheteistkümnest uudisterminist on laialdasemas kasutuses (s.t nende kasutus 2009. aastal moodustas enam kui $16 \%$ kogukasutusest) sõnad üleilmastumine, lõimumine, tõukefondid, vabaühendus ja õigustik. Korpuseandmete põhjal ei ole kasutusse läinud sõnad kriisiohjamine ja täisleppimatus. Madala kasutussageduse tõttu ajakirjandustekstides ei olnud täpsemalt võimalik analüüsida uudisvormide sihtkomisjon, lähimus, rakkerühm ja mestimine levikut.

2. Uute vormide leviku tõenäosus ja kiirus ei ole korrelatsioonis sõna väljapakkunud inimeste arvuga. Sõnade levik sõltub ennekõike nende suupärasusest ning mõnevõrra üllatuslikult ka poliitilisest tahtest: keelendite lähimus, kriisiohjamine ja tõukefondid edasist levikut pidurdab paljuski riigiasutuste soovimatus uudisterminid kasutusele võtta. Euroopa Liiduga seotud juriidiliste terminite muutmine takerdub tihti lepingutekstide järjepidevuse küsimusse.

3. Uudisvormi kasutuselevõtuga võib kaasneda tähendusenihe, samuti võib üks tüvi jääda eelistatuks teatud ühenduses (nt tänapäeva globaliseeruv maailm, integratsiooniprogramm vs. lõimumiskava).

4. Uudiskeelendite leviku dünaamika ei järgi üldjuhul Everett M. Rogersi uuenduste leviku mudelit: siinses artiklis allus mudelile väga hästi vaid sõna üleilmastumine levik (mööndustega ka sõnade lõimima/lõimuma ja õigustik levik). Uuenduse leviku dünaamikat võib mõjutada uue vormi keeleline mugandamine (Rogersi järgi „taasleiutamine”): nt vormi lõimimine järkjärguline asendumine vormiga lõimumine. Uute vormide leviku kiirust on raske ette ennustada, sest see on dünaamiline suurus, mis võib vaid ühe aastaga järsult muutuda. Sõnade levik võib erinevate välismõjurite toimel järsult pidurduda, välistatud pole isegi taandareng. Samalaadsetele järeldustele on jõutud ka J. Aaviku tehissõnade levikut uurides (Chalvin 2011).

5. Uuritud uudisvormide leviku sotsiaalseid aspekte aitab selgitada lihtne matemaatiline sotsiaalvõrgustiku mudel (Fagyal jt 2010).

Siinses uurimuses käsitleti vaadeldud sõnavõistluse uudissõnade levikut vaid ühe väljaande näitel, põhjalikumad uuringud peavad jääma ootama korraliku 2000. aastate eesti keele korpuse valmimist.

\section{Kirjandus}

B i b e r, Douglas 1993. Representativeness in Corpus Design. - Literary and Linguistic Computing, kd 8, nr 4, lk 243-257.

BNS 2000 = Eesti lubab EL-i kiirreageerijatele pataljoni. - Eesti Päevaleht 21. XI .

$\mathrm{C}$ h a lvi in, Antoine 2011. Johannes Aaviku keeleliste uuenduste levik. - Keel ja Kirjandus, nr 7, lk 487-504.

$\mathrm{C} \mathrm{h}$ a $\mathrm{m}$ b e r s, J. K. 2002. Patterns of variation including change. - The Handbook of Language Variation and Change. Toim J. K. Chambers, P. Trudgill, N. Schilling-Estes. Oxford: Blackwell, lk 349-372.

$\mathrm{E}$ h a la, Martin 2011. The diffusion of impositional innovations in the Estonian object-marking system. - Diachronica, kd 28, nr 3, lk 324-344.

EKK = eesti keele Koondkorpus, http://www.cl.ut.ee/korpused/segakorpus/epl/ EPL 2002 = Eesti keelde tekkisid uued sõnad. - Eesti Päevaleht 29. XI. 
E r e l t, Tiiu 2003. Sõnavõistlus andis uued eesti sõnad. - Oma Keel, nr 1, lk 5-19.

E r e lt, Tiiu, K u 11, Rein, M e r i s t e, Henno 1985. Uudis- ja unarsõnu. Tallinn: Valgus.

ETA 2000 = NATO hindab Eesti alliansiga liitumise plaani realistlikuks. - Eesti Päevaleht 7. XI.

F a g y a l, Zsuzsanna, Sw a r u p, Samarath, Es c ob a r, Anna Maria, G a s s e r, Leo, L a k k a r a j u, Kiran 2010. Centers and peripheries: Network roles in language change. - Lingua, kd 120, nr 8, lk 2061-2079.

G e r o w, Aron, K e a n e, Mark T. 2011. Mining the Web for the „Voice of the Herd” to Track Stock Market Bubbles. - Proceedings of the $22^{\text {nd }}$ International Joint Conference on Artificial Intelligence. Barcelona, lk 2244-2249.

Habicht, Külli 2005. Eesti kirjakeele hetkeseis: tähelepanekuid ja probleeme (ettekanne seminaril „Muutuv eesti keel”). www.fl.ut.ee/orb.aw/class=file/ action=preview/id=118448/kyllihabicht.doc -19 . VIII 2012.

H e i n e, Bernd 1993. Auxiliaries. Cognitive Forces and Grammaticalization. New York-Oxford: Oxford University Press.

H o p p e r, Paul J., Tr a u g t t, Elizabeth Closs 2003. Grammaticalization. Cambridge: Cambridge University Press.

Ka ljuvee, Ardo 2008a. Kellel on Eestis hea elada? - Eesti Päevaleht 22. II (www.epl.ee/artikkel/419451 - 8. IX 2012).

K a lj u ve e, Ardo 2008b. Venelastele näppu viskamas. - Eesti Päevaleht 18. VI (http://www.epl.ee/artikkel/435742 - 9. IX 2012).

K a lj u ve e, Ardo 2009. Järgmine üleilmastumise lõpp. - Eesti Päevaleht 27. II (http://www.epl.ee/artikkel/460378 - 19. VIII 2012).

K a s i k, Reet 2004. Muutuv meedia - muutuv keel. - Oma Keel, nr 2, lk 5-14.

Kres s a, Kaarel 2008. Kliimamuutus ajas ürginimese rändama. - Eesti Päevaleht 30. VIII (http://www.epl.ee/artikkel/440095 - 19. VIII 2012).

Kress a, Kaarel 2009. Jaak Valge: oleme tarbimiskultuuri pantvangid. - Eesti Päevaleht 20. VI (http://www.epl.ee/artikkel/471783 - 19. VIII 2012).

Kr u u s e, M. 2008a. Euroopa Nõukogu lõi Vene-Gruusia sõja ad hoc komitee. Eesti Päevaleht 5. IX (http://www.epl.ee/artikkel/440743 - 18. VIII 2012).

Kr u u s e, M. 2008b. Euroopa Nõukogu hakkab Venemaa volituste peatamist arutama. - Eesti Päevaleht 10. IX (http://www.epl.ee/artikkel/441247 - 18. VIII 2012).

Kr u u s e, M. 2008c. Venemaa esindaja eemaldati Vene-Gruusia sõja ad hoc komiteest. - Eesti Päevaleht 10. IX (http://www.epl.ee/artikkel/441224 - 18. VIII 2012).

L a b o v, William 1972a. Language in the Inner City: Studies in Black English Vernacular. Philadelphia: University of Philadelphia Press.

L a b o v, William 1972b. The social motivation of a sound change. - W. Labov, Sociolinguistic Patterns. Philadelphia: University of Pennsylvania Press, lk 142.

L u r a g h i, Silvia 2010. Causes of language change. - The Continuum Companion to Historical Linguistics. Toim S. Luraghi, V. Bubenižk. London: Continuum Publishing, lk 358-370.

M a k k o, Maris 2005. Kes otsustab, mis sõnadega teeme seadusi? - Eesti Päevaleht 14. V (http://www.epl.ee/news/kultuur/kes-otsustab-mis-sonadega-teemeseadusi.d?id=51010554 - 18. XI 2012). 
M i c h e l, Jean-Baptiste, Sh e n, Yuan Kui, A i d e n, Aviva Presser, V e r e s, Adrian, Gr a y, Matthew K., The Google Books Team, P i c k e t t, Joseph P., H o l b e r g, Dale, C l a n c y, Dan, N o r vi g, Peter, O r w a n t, Jon, P i n k e r, Steven, N ow a k, Martin A., Li e b e r m a n A i d e n, Erez 2011. Quantitative Analysis of Culture Using Millions of Digitized Books. - Science, kd 331, lk 176-182.

M i h k la, Kadi 2010. Võõrsõnad Eesti õigusaktides ja Euroopa Liidu õigusaktide tõlgetes (magistritöö). Tallinn: Tallinna Ülikool.

Milroy, James, Milroy, Lesley 1985. Linguistic change, social network and speaker innovation. - Journal of Linguistics, kd 21, nr 2, lk 339-384.

M u n d, Argo 2007. ÕS sstruktuurifond\} tõukefond. - Sirp 20. IV.

N e i v e l t, Indrek 2009. U, V, W või L? Missugune on majanduse tulevik? - Eesti Päevaleht 30. X (http://www.epl.ee/artikkel/481397 - 19. VIII 2012).

N e t $t$ l e, Daniel 1999. Using Social Impact Theory to simulate language change. Lingua, kd 108, nr 2-3, lk 95-117.

O w e n, David 2007. Euroopa tulevik. - Eesti Päevaleht 30. III (http://www.epl.ee/ artikkel/380183 - 9. IX 2012).

$\mathrm{R}$ a a g, Raimo 2008. Talurahva keelest riigikeeleks. Tartu: Atlex.

$\mathrm{R}$ a a g, Virve 1998. The Effects of Planned Change on Estonian Morphology. Acta Universitatis Upsaliensis. (Studia Uralica Upsaliensia 29.) Uppsala: Uppsala University.

R e k a n d, Tiina, R a t t, Kadri 2010. Presidendi sõnavõistlusele laekus 2030 sõna. - Postimees 5. X (http://www.postimees.ee/322287/presidendi-sonavoistluselelaekus-2030-sona - 18. VIII 2012).

R o g e r s, Everett M. 1962. Diffusion of Innovations. 1. tr. New York: Free Press.

R o g e r s, Everett M. 2003. Diffusion of Innovations. 5. tr. New York: Free Press.

R õ õ m, Rein 2010. Tõenäosusteooria ja statistika. Tartu: Tartu Ülikool. - http:// ael.physic.ut.ee/KF.Private/Aare.Luts/03006/I_vihik.pdf (13. II 2013).

S a l u, Mikk 2009, Indrek Neivelt: välismaa omanikud müüvad tütarfirmad Eesti tegijatele. - Eesti Päevaleht 6. II (http://www.epl.ee/artikkel/457898 - 19. VIII 2012).

T a r d e, Gabriel de 1903. The Laws of Imitation. New York: Holt; Chicago: University of Chicago Press.

W e i n r e i c h, Uriel, L a b o v, William, H e r z o g, Marvin I. 1968. Empirical foundations for a theory of language change. - W. P. Lehmann, Y. Malkiel (toim), Directions for Historical Linguistics: A Symposium. Austin: University of Texas Press, lk 95-195.

W o lfr a m, Walt, S c h i l ling - E s t e s, Natalie 2003. Dialectology and linguistic diffusion. - The Handbook of Historical Linguistics. Toim B. D. Joseph, R. D. Janda. Malden: Blackwell, lk 713-735. 


\section{On the Diffusion of Some Recently Proposed Estonian Words}

Keywords: diffusion of innovations, new word contest, sociolinguistics

In 2002, a new word contest was held in Estonia, which resulted in the proposition of eleven new words to replace some of the foreign loanwords often used in the context of European legislation. The main goal of this article was to investigate whether these new words have gone through successful diffusion (as described by E. Rogers, 2003) or whether they have been rejected by the general public. Additionally, through the use of corpora texts, the dynamics of the diffusion could be mapped and compared to the predictions of some recent mathematical models (such as that of Fagyal et al, 2010).

It was found that out of the eleven words proposed, five were in wider use. These words were üleilmastumine 'globalization', lõimumine 'integration', tõukefondid 'structural funds', vabaühendus 'non-governmental organization', õigustik 'acquis'. In contrast, the use of words such as kriisiohjamine 'crisis management' and täisleppimatus 'zero tolerance' had, as of 2009, not been adopted by the general public. Low frequency in corpora did not allow closer analysis of other words proposed during the contest.

The diffusion of new words does not generally follow the S-shaped diffusion pattern proposed by Rogers. It was further found that the rate of diffusion is typically not constant over time: the process of diffusion can stop or even reverse unexpectedly (in agreement with recent results by Chalvin, 2011).

Rainer Küngas (b. 1984), PhD, language enthusiast and participant in the 2002 Estonian new word contest, rainerkungas@gmail.com 